\title{
MODIFICATION AND ALLOYING EFFECTS IN EUROFER STEEL UNDER POWERFUL PULSED PLASMA IMPACTS
}

\author{
O.V. Byrka ${ }^{1}$, S.S. Herashchenko ${ }^{1,2}$, V.A. Makhlai, ${ }^{1,2}$, N.N. Aksenov ${ }^{1}$, I.E. Garkusha ${ }^{1,2}$, \\ H.K. Marchenko , A.G. Chunadra', K.N. Sereda ${ }^{2}$, S.V. Malykhin ${ }^{3}$, S.V. Surovitskiy ${ }^{3}$ \\ ${ }^{1}$ National Science Center “Kharkov Institute of Physics and Technology”, Kharkiv, Ukraine; \\ ${ }^{2}$ V.N. Karazin Kharkiv National University, Kharkiv, Ukraine; \\ ${ }^{3}$ NTU “Kharkov Polytechnic Institute", Kharkiv, Ukraine \\ E-mail: byrka@kipt.kharkov.ua
}

Experimental studies of surface modification of Eurofer samples have been performed with a quasi-stationary plasma accelerator QSPA Kh-50. The heat load on the surface was near the tungsten melting threshold (i.e. about $0.6 \mathrm{MJ} / \mathrm{m}^{2}$ ). The plasma streams exposures result in modification of steel-based materials and formation of cellular submicron structures in re-solidified layers. Phase characterized by body-centered cubic lattice appeared due to recrystallization of affected material.

PACS: 52.40.Hf

\section{INTRODUCTION}

In the last few years, special steel grades have been developed to fulfill strict long-term safety and environmental requirements for wall materials in magnetic and inertial fusion devices. These are reduced-activation ferritic/martensitic (RAFM) steels with about $8 \ldots 11$ wt.\% chromium Cr. RAFM steels are proposed as structural materials for fusion reactors due to their high swelling resistance and low irradiation creep-rates (i.e. slow changes in dimensions of materials exposed to prolonged stresses, caused by X-rays, $\gamma$-rays and neutron irradiation, etc.). In particular, such steels might be a possible option at the choice of plasma facing materials for the first wall surfaces in Magnetic and Inertial Fusion devices [1 - 3].

The main drawback of such steels at their application as the plasma facing materials is their high sputtering rate under influence of energetic ions (particularly hydrogen isotopes). It is directly related with the generation of impurities as well as with a lifetime of the plasma facing components [3, 4]. One of the prospective ways towards an improvement of the steel properties is the alloying of their surface layers with some refractory elements [3]. Plasma ions can of course be considered as a source of the alloying elements which should be introduced into a modified layer structure [5]. Another possibility of the alloying during the pulsed plasma processing is the mixing of previously deposited thin $\left(h_{\text {coat }}<h_{\text {melt }}\right)$ coatings of a different pre-determined composition with the chosen substrate in the course of its melting driven by powerful plasma impacts [6 - 9].

Analyses and comparisons of experimental results of research on RAFM steel behaviour under their irradiation with high-power pulsed plasma streams, which can be generated in plasma devices. They can give the unique possibility to understand the important common features of surface damages at extreme conditions, to investigate the peculiarities of the surface modification of low-activation steels and possible erosion mechanisms in dependence on the plasma parameters and the impact load.
First results, was demonstrated that the modified tungsten coatings delaminated from the steel substrates. As results, spattering resistance of modified surface not improved [9]. A possible way to improve the coatings resistance might be the application of several cycles of the plasma treatment.

This paper presents experimental studies of the modification of the ferritic/martensitic Eurofer steel (Cr$9.7 \%$, Mn- $0.7 \%$, W- $0.8 \%$, Fe- $89.6 \%$ ) with some tungsten admixture introduced by the plasma-induced mixing. There are also discussed studies of the sputtering of the surfaces covered by tungsten and exposed to powerful plasma streams.

\section{SAMPLES, EXPERIMENTAL DEVICES AND DIAGNOSTICS}

Samples of the Eurofer alloy (Cr-9.7\%, Mn- $0.7 \%$, $\mathrm{W}-0.8 \%, \mathrm{Fe}-89.6 \%$ ) were applied in the reported experiments (Table). The samples had the size of $10 \times 10 \times 1 \mathrm{~mm}$. All specimens were mechanically polished to the mirror-like surface.

Element content (wt. \%) of Eurofer

\begin{tabular}{|l|c|c|c|}
\hline \multicolumn{1}{|c|}{ Parameters } & $\mathrm{Cr}$ & $\mathrm{W}$ & $\mathrm{Fe}$ \\
\hline Initial & 9.7 & 0.8 & base \\
\hline $\mathrm{W}+$ QSPA (single) & 1.3 & 85.8 & base \\
\hline $\mathrm{W}+$ QSPA (twice) & 7.11 & 27.46 & base \\
\hline Ar-beam & 9.9 & 1.3 & base \\
\hline
\end{tabular}

Some samples were covered by tungsten coatings, which were deposited with a PVD technique [7 - 9] within a Bulat-type facility. Earlier such coatings were applied for estimations of their performance as plasma facing surfaces (in a comparison with monolithic tungsten targets). They enabled also an analysis of the adhesion properties of the PVD coatings, and an investigation of the plasma facing components prospective for the reactor first wall construction [8].

Surface modifications by powerful pulsed plasma streams were carried out with the use of a QSPA Kh-50 quasi-stationary plasma accelerator [8]. The main parameters of the QSPA hydrogen plasma streams were as 
follows: ion impact energy was about $0.4 \ldots 0.6 \mathrm{keV}$, the maximum plasma pressure reached up to $0.32 \mathrm{MPa}$, and the plasma stream diameter was about $18 \mathrm{~cm}$. The surface energy loads, as measured with a calorimeter, amounted to $0.6 \mathrm{MJ} / \mathrm{m}^{2}$. The load pulse shape was approximately triangular, and the pulse duration was $0.25 \mathrm{~ms}$.

The sputtering procedures were performed within the DSM-2 stand described in an earlier paper [9]. An ion source was the system based on a microwave discharge in argon within a mirror magnetic trap, which was operated at the electron cyclotron resonance (ECR) frequency of $2.37 \mathrm{GHz}$. The plasma density $n_{e}$ in this system was about $10^{10} \mathrm{~cm}^{-3}$, and the electron temperature $T_{e}$ reached about $5 \mathrm{eV}$. The plasma ions were accelerated by a negative potential $(-600 \mathrm{~V})$ applied to the water-cooled holder. The density of the ion current upon the mirror surface was equal to $1.6 \mathrm{~mA} / \mathrm{cm}^{2}$.

The energy density in free plasma and the surface heat loads were measured by means of the local calorimeters. Observations of plasma interactions with the exposed surfaces were performed with a high-speed 10bit CMOS pco.1200s digital camera of the PCO AG type. The surface analysis of the exposed samples was carried out with a SEM. There were also performed measurements of weight losses, as well as precise measurements of the surface roughness with a Hommelwerke T500 tester. To study a micro-structural evolution and contents of elements and phases in the exposed targets, the X-ray diffraction technique (XRD) was applied $[10,11]$.

\section{EXPERIMENTAL RESULTS}

\subsection{INITIAL STATE OF EUROFER SAMPLE SURFACES}

The morphology of the initial samples of Eurofer steel did not have any significant features (Fig. 1). All specimens were mechanically polished to the mirrorlike surface. The initial microhardness and roughness of Eurofer samples were $200 \mathrm{~kg} / \mathrm{mm}^{2}$ and $\mathrm{R}_{\mathrm{a}} \leq 0.01 \mu \mathrm{m}$, $\left(\mathrm{R}_{\max } \leq 0.01 \mu \mathrm{m}\right)$ respectively.

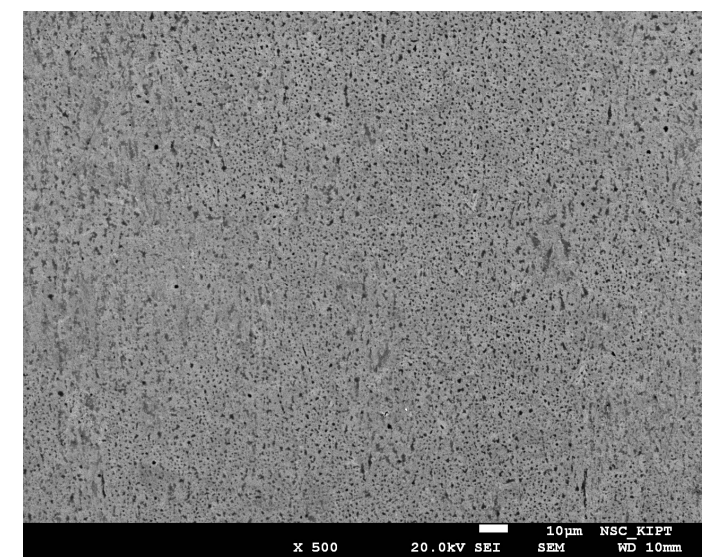

Fig. 1. SEM image of the initial Eurofer sample surface

During XRD structural studies of the samples surfaces there were observed lines corresponding to the $\alpha$-Fe phase only (Fig. 2,a). It should be noted that to that phase there was attributed the body-centred cubic crystal structure.
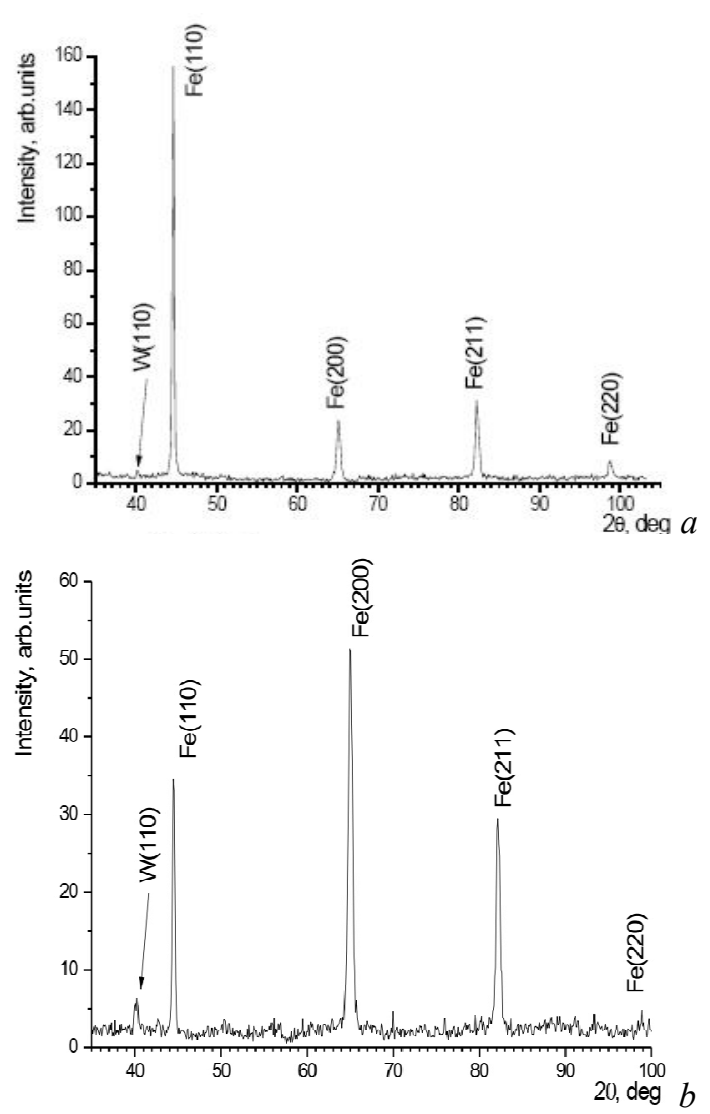

Fig. 2. Diffraction patterns ( $\mathrm{Cu}-K_{\alpha 1}$ radiation) of the Eurofer sample measured in the initial state (a) and after deposition of W-layer, modification by QSPA plasma and sputtered by the Ar+ beam (b)

\subsection{SURFACE MODIFICATION OF EUROFER STEEL BY POWERFUL PLASMA}

For stainless steel the melting threshold is experimentally evaluated as $0.5 \ldots 0.6 \mathrm{MJ} / \mathrm{m}^{2}$ for applied QSPA plasma pulses. From this reason, the heat load to the target surface was chosen to be on the level of $0.6 \mathrm{MJ} / \mathrm{m}^{2}$ (i.e., in the vicinity of the tungsten melting threshold). Irradiations of the Eurofer samples by plasma streams within the QSPA led to the surface melting and resulted in the development of re-solidified surface layers, which are presented in Fig. 3,a.

The roughness of the initial surfaces was noticeably increased due to the boundaries of the grains and formation of fine cellular structure of the surface layer, as shown in Fig. 3,b. Typical size of the cellular structures is $150 \ldots 250 \mathrm{~nm}$.

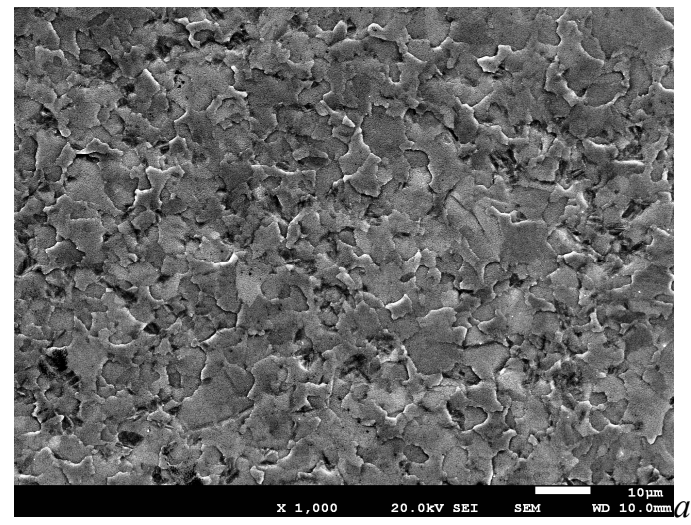




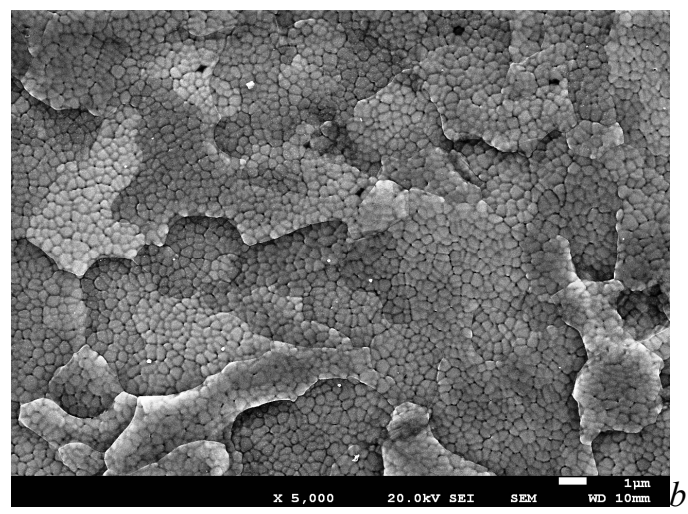

Fig. 3. SEM images with different magnification

of Eurofer sample surface after the QSPA exposure with heat load of $0.6 \mathrm{MJ} / \mathrm{m}^{2}$

\subsection{MODIFICATION OF TUNGSTEN COATINGS DEPOSITED ON EUROFER STEEL SUBSTRATES}

The process of the steel-surface alloying consisted of two stages. During the first stage the tungsten coating was deposited upon the sample surface by means of the PVD method. After the deposition of the tungsten coatings on the Eurofer surfaces their roughness was slightly increased. During the second stage the W-coated samples were exposed to plasma stream in the QSPA device (10 plasma pulses with heat load $0.6 \mathrm{MJ} / \mathrm{m}^{2}$, fluence of $4 \cdot 10^{24} \mathrm{~m}^{-2}$ ).

Surface modification led to penetration of tungsten in affected layer. W phases are recognized together with lines of $\mathrm{Fe}$ phase on treatment surfaces. Intensity of tungsten lines is more at times in compare with intensity of substrate lines. An increase in the tungsten concentration (up to several wt. \%) was observed upon the modified surfaces (see Table).

The surface morphology is developed mostly by melting and re-solidification of a surface layer. Macro and micro cracks appear also on modified surfaces. The roughness of the exposed surfaces increased up to $\mathrm{R}_{\mathrm{a}} \approx 0.3 \mu \mathrm{m}$ $\left(\mathrm{R}_{\max } \approx 3.4 \mu \mathrm{m}\right)$, microhardness $-260 \mathrm{~kg} / \mathrm{mm}^{2}$. Due to not very good adhesion of tungsten coatings and steel substrate are observed some delamination of coatings.

Thus, two cycles of plasma treatment were used to improve the stability of the coatings. Each cycle included the application of PVD method of tungsten coating with a thickness of $\approx 2 \mu \mathrm{m}$ and treatment with 5 plasma pulses.

Coatings delamination from the Eurofer surface was not observed during the first cycle of irradiation by plasma-streams. The tungsten concentration in the surface layer reached $85.8 \%$ (see Table). However, some delamination of these coatings was observed on the Eurofer surface covered with $\mathrm{W}$ layers upon repeated (second cycle) irradiation. The tungsten concentration in the surface layer decreased to $27.5 \%$.

\subsection{SPUTTERING TESTS OF EUROFER STEEL}

The sputtering tests of Eurofer samples were carried out for the initial surfaces, as well as for those coated by a W-layer and those modified by plasma-streams. The exposure parameters were selected so that the total fluence (plasma and/or sputtering procedure) was equivalent to $4 \cdot 10^{24} \mathrm{~m}^{-2}$ for each sample.
The sputtering yield was evaluated by weight-loss. The sample weight was measured before and after irradiation. The sputtering yield was then calculated from the weight loss. The sputtering yield of samples modified by plasma and yield of samples in initial state are differed negligibly. The roughness of the initial surfaces was noticeably increased due to the sputtering of boundaries of the grains (Fig. 4).

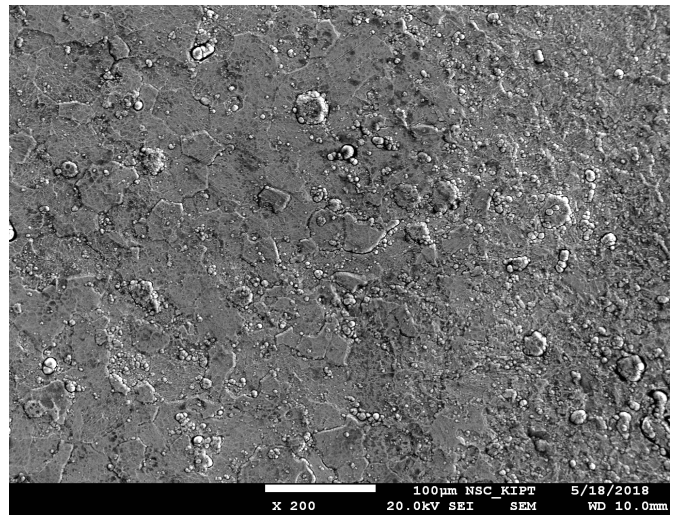

Fig. 4. SEM image of the Eurofer surface coated by a $W$-layer and exposed to 10 plasma pulses and sputtered by the Ar+ beam

Another result was observed for tungsten-coated Eurofer samples. W phases are recognized together with lines of $\mathrm{Fe}$ phase on treatment surfaces. Intensity of tungsten lines is more at times in compare with intensity of substrate lines (see Fig. 2,b). The mass losses for targets-coated samples and subsequently modified by plasma streams were significantly less (up to 1.5 times) than for pure samples.

\section{SUMMARY}

Experimental studies of surface modification of Eurofer samples have been performed with a quasistationary plasma accelerator QSPA Kh-50. The heat load to the target surface was chosen to be on the level of $0.6 \mathrm{MJ} / \mathrm{m}^{2}$. The preliminary tungsten coatings were deposited by a PVD method. The sputtering tests of modified surfaces were also performed with Argon ion beam with energy of $600 \mathrm{eV}$ and current density of $1.6 \mathrm{~mA} / \mathrm{cm}^{2}$.

The possibility of alloying of Eurofer surfaces with tungsten was demonstrated. Tungsten phase is recognized together with lines of Fe phase on treatment surfaces. The concentration of tungsten has been achieved several tens wt. $\%$ in surface layer up to $4 \mu \mathrm{m}$. The surface morphology is developed mostly by melting and re-solidification of a surface layer. Formation of fine cellular structure of the surface layer with typical cell size of $150 \ldots 250 \mathrm{~nm}$ has been discovered as result of pulsed plasma exposures.

The sputtering yield of samples modified by plasma and yield of samples in initial state are differed negligibly. At the same time, mixing the previously applied tungsten coating leads to the decrease of sputtering up to 1.5 times.

\section{ACKNOWLEDGEMENT}

This work has also been supported by National Academy Science of Ukraine projects X-2-11-10/2021, $\Pi-2 / 24-2021$ and IAEA's CRP F13020. The work is 
partially supported by the Ministry of Education and Science of Ukraine research grant № M/122-2020.

\section{REFERENCES}

1. A.F. Tavassoli et al. Current status and recent research achievements in ferritic/martensitic steels // J. Nucl. Materials. 2014, v. 455, p. 269-276.

2. N. Baluc et al. Microstructures of brazed and solidstate diffusion bonded joints of tungsten with oxide dispersion strengthened steel // Plasma Phys. Control. Fusion. 2006, v. 48, p. B165-B177.

3. J.W. Coenen et al. Materials for DEMO and reactor applications boundary conditions and new concepts // Physica Scripta. 2016, v. T167, p. 014002.

4. W. Jacob et al. Sputtering of iron, chromium and tungsten by energetic deuterium ion bombardment // Nuclear Materials and Energy. 2016, v. 8, p. 1-7.

5. V.I. Tereshin et al. Pulsed plasma accelerators of different gas ions for surface modification // Rev. Sci. Instrum. 2002, v. 73, p. 831-833.
6. V.A. Makhlay et al. Features of materials alloying under exposures to pulsed plasma streams // Eur. Phys. J. 2009, v. D. 54, p. 185-188.

7. V. Tereshin et al. Coating deposition and surface modification under combined plasma processing // Vacuum. 2004, v. 73, p. 555-560.

8. I.E. Garkusha et al. Simulation of plasma-surface interactions in a fusion reactor by means of QSPA plasma streams: recent results and prospects // Phys. Scripta. 2016, v. 91, p. 094001.

9. I. Garkusha et al. Materials surface damage and modification under high power plasma exposures // Journal of Physics: Conf. Series. 2018, v. 959, p. 012004.

10. V.A. Makhlaj et al. Residual stresses in tungsten under exposures with ITER ELM-like plasma loads // Physica Scripta. 2009, v. T138, p. 014060.

11. S.V. Malykhin et al. On application of X-ray aproximation method for studying the substructure of sufficiently perfect samples // Functional Mater. 2017, v. 24(1), p. 179-183.

Article received 03.06.2021

\section{ЭФФЕКТЫ МОДИФИКАЦИИ И ЛЕГИРОВАНИЯ СТАЛИ ЕUROFЕR ПРИ МОЩНЫХ ИМПУЛЬСНЫХ ПЛАЗМЕННЫХ ВОЗДЕЙСТВИЯХ}

\section{О.В. Бырка, С.С. Геращенко, В.А. Махлай, Н.Н Аксенов, И.Е. Гаркуиа, А.К. Марченко, А.Г. Чунадра, К.Н. Середа, С.В. Малыхин, С.В. Сыровицкий}

Экспериментальные исследования модификации поверхности образцов Eurofer проводились на квазистационарном плазменном ускорителе КСПУ Х-50. Тепловая нагрузка на поверхность была близка к порогу плавления вольфрама (то есть около 0,6 МДж/м²). Воздействие плазменных потоков приводит к модификации стали Eurofer и формированию субмикрометровых ячеистых структур в приповерхностном слое. Фаза, которая характеризуется объемно-центрированной кубической решеткой, появилась в результате рекристаллизации облученного материала.

\section{ЕФЕКТИ МОДИФІКАЦЇ̈ ТА ЛЕГУВАННЯ СТАЛІ ЕUROFЕR ПРИ ПОТУЖНИХ ІМПУЛЬСНИХ ПЛАЗМОВИХ ВПЛИВАХ}

\section{О.В. Бирка, С.С. Геращценко, В.О. Махлай, М.М. Аксьонов, І.С. Гаркуша, Г.К. Марченко, А.Г. Чунадра, К.М. Середа, С.В. Малихін, С.В. Сировицький}

Експериментальні дослідження модифікації поверхні зразків Eurofer проводилися на квазі-стаціонарному плазмовому прискорювачі КСПП Х-50. Теплове навантаження на поверхню було близьке до порогу плавлення вольфраму (тобто близько 0,6 МДж/м²). Вплив плазмових потоків призводить до модифікації сталі Eurofer та формування субмікрометрових стільникових структур у приповерхневому шарі. Фаза, яка характеризується об'ємно-центрованою кубічною решіткою, з'явилася внаслідок рекристалізації опроміненого матеріалу. 